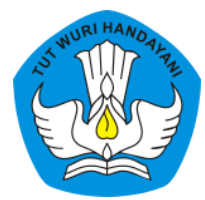

Page: 91-108

\title{
PENGGUNAAN POWTAKON KARDUS SEBAGAI UPAYA MENINGKATKAN HASIL BELAJAR PESERTA DIDIK SDN 2 KEMBANG
}

\author{
Nurma Zuliyanti \\ Sekolah Dasar Negeri 2 Kembang Jepara, Jawa Tengah, Indonesia \\ Contributor Email: nurmazuliyanti01@gmail.com
}

Received: Feb 13, 2021

Accepted: Mar 9, 2021

Published: Mar 30, 2021

Article Url: https://ojsdikdas.kemdikbud.go.id/index.php/didaktika/article/view/289

\begin{abstract}
These classroom action research aims: To improve student learning outcomes using Powtakon kardusmedia. The research setting was grade $V$ students of SDN 2 Kembang Jepara for the 2019/2020 academic year. This study consisted of 2 cycles in one basic competency. The research begins with compiling a lesson plan, making observation sheets and other research instruments. During the learning process, observations were made on the performance of the teacher as a researcher and an assessment was made of students through test sheets. Other findings during the learning process were discussed between the researcher and the observer, equipped with data from observations made by reflection at each meeting. The results of research in cycle 1 and cycle 2 showed an increase in student learning outcomes. The student learning outcomes are in cycle 1 an average of 66.33 with learning completeness $40 \%$, in cycle 2 an average of 81.27 with learning completeness $86.67 \%$. Based on the results of the study, it can be concluded that the learning process using powtakon kardusmedia can improve student learning outcomes in Class V SDN 2 Kembang Jepara for the 2019/2020 academic year.
\end{abstract}

Keywords: Powtakonkardus; Learning Outcomes; 


\begin{abstract}
Abstrak
Penelitian tindakan kelas ini bertujuan: Untuk meningkatkan hasil belajar peserta didik dengan menggunakan media Powtakon kardus. Penelitian tindakan kelas ini dilakukan pada peserta didik kelas V SDN 2 Kembang Jepara Tahun Pelajaran 2019/2020. Penelitian ini terdiri dari 2 siklus dalam satu kompetensi dasar. Penelitian diawali dengan menyusun rencana pembelajaran, membuat lembar observasi yang digunakan dan instrumen penelitian lainnya. Selama proses pembelajaran, dilakukan pengamatan terhadap kinerja guru sebagai peneliti dan dilakukan penilaian terhadap peserta didik melalui lembar tes. Temuan lain selama berlangsungnya pembelajaran didiskusikan antara peneliti dengan observer dilengkapi dengan data hasil pengamatan yang dilakukan refleksi pada setiap pertemuan. Hasil penelitian pada siklus 1 dan siklus 2 menunjukkan adanya peningkatan hasil belajar peserta didik. Hasil belajar peserta didik pada siklus 1 ratarata 66,33 dengan ketuntasan belajar 40\%, pada siklus 2 rata-rata 81,27 dengan ketuntasan belajar 86,67\%. Berdasarkan hasil penelitian dapat disimpulkan bahwa proses pembelajaran dengan menggunakan media powtakon kardus dapat meningkatkan hasil belajar peserta didik KelasV SDN 2 Kembang Jepara Tahun Pelajaran 2019/2020.
\end{abstract}

Kata Kunci: Powtakon kardus; Hasil Belajar;

\title{
A. Pendahuluan
}

Pembelajaran yang menyenangkan akan menyebabkan peserta didik terlibat secara aktif. Peserta didik yang terlibat secara aktif dalam membahas materi yang dipelajari maka hasilnya akan terkesan. Dengan demikian pemahaman akan materi yang dipelajari sangat kuat. Intinya, materi yang dipelajarinya kemudian menyatu dengan diri peserta didik. Oleh karena itu, guru dituntut untuk menciptakan media pembelajaran yang menyenangkan. Media pembelajaran mempunyai peranan yang sama pentingnya dengan faktor-faktor pendidikan yang lain, tetapi terkadang kurang diperhatikan guru. Padahal dengan pemilihan media yang tepat, merupakan kunci keberhasilan suatu proses belajar mengajar. Proses pembelajaran pada dasarnya adalah proses komunikasi yang diwujudkan melalui kegiatan penyampaian informasi kepada peserta didik (Andi Prastowo, 2012) 
SD Negeri 2 Kembang, Kecamatan Kembang, yang lokasinya di pinggiran Kabupaten Jepara, berdasarkan hasil observasi sementara menunjukkan bahwa penggunaan media pembelajaran dalam mata pelajaran Ilmu Pengetahuan Sosial masih sangat sedikit apabila dibandingkan dengan Matematika dan Ilmu Pengetahuan Alam, hal ini merupakan salah satu kendala dalam pembelajaran di SD Negeri 2 Kembang Jepara, karena keberhasilan peserta didik bukan hanya ditentukan oleh pemahaman konsep peserta didik saja tetapi juga kinerja peserta didik untuk meningkatkan hasil belajar. Akibatnya banyak peserta didik yang memperoleh hasil belajar yang tidak sesuai dengan yang diharapkan. Sebagian peserta didik mengalami kesulitan belajar, kurang memahami konsep-konsep IPS yang dipelajari, aktivitas peserta didik dalam pembelajaran cenderung pasif, serta yang paling berbahaya adalah menganggap apa yang dipelajari tidak ada kaitannya dengan kehidupan peserta didik sehari-hari dan memahami IPS dalam tema peristiwa dalam kehidupan hanya secara parsial. Sebagian besar dari peserta didik tidak mampu menghubungkan antara apa yang mereka pelajari dengan bagaimana pengetahuan tersebut akan dipergunakan/dimanfaatkan dalam kehidupannya. Hal tersebut menyebabkan peserta didik kurang senang dan memiliki penilaian negatif terhadap materi. Akibatnya penguasaan peserta didik terhadap materi pembelajaran kurang optimal yang berdampak kepada hasil belajar yang belum memuaskan. Karena kurangnya media pembelajaran yang inovatif dan menyenangkan maka hasil belajar IPS dalam tema peristiwa dalam kehidupan rendah (Siswanto, Sugiono \& Prasojo, 2018). Peserta didik kelas V SD Negeri 2 Kembang Jepara nilai pemahaman dan penerapan konsep IPS dalam tema peristiwa dalam kehidupan masih rendah dan belum mencapai tuntas belajar.

Hasil pengamatan terhadap proses pembelajaran yang dilakukan guru pada kondisi awal menunjukkan bahwa peserta didik kurang antusias dalam menerima pembelajaran. Ada peserta didik yang bicara 
dengan teman sebangkunya, ada yang meletakkan kepala di bangku, dan ada pula yang bermain-main sendiri ketika guru menerangkan. Peserta didik merasa bosan terhadap pembelajaran yang dilakukan guru. Di mata Peserta didik, pembelajaran yang dilakukan guru kurang mengembangkan kegembiraan sehingga peserta didik merasa bosan.

Menghadapi permasalahan seperti di atas tentu bukan pekerjaan yang mudah bagi guru untuk memilih media pembelajaran. Kearifan, pengalaman, dan kreativitas mutlak diperlukan bagi seorang guru untuk membantu peserta didik dalam rangka memecahkan kesulitan yang dihadapi.

Berpijak dari permasalahan yang melatarbelakangi, guru mencoba menggunakan media powtakon kardus pada mata pelajaran IPS dalam tema peristiwa dalam kehidupan di kelas V SDN 2 Kembang Jepara. Media pembelajaran ini memfasilitasi peserta didik untuk mengembangkan kegembiraan dalam proses belajar mengajar, mampu menghilangkan sifat egoisme peserta didik. Media pembelajaran merupakan sesuatu yang digunakan untuk menyampaikan pesan yang dapat merangsang pikiran, perhatian dan perasaan serta kemauan peserta didik yang dapat membuat senang dalam proses pembelajaran (Miarso, 2011). Sejalan dengan pendapat tersebut Indriana (2011) menyampaikan media merupakan alat bantu yang sangat bermanfaat untuk peserta didik dan guru dalam proses pembelajaran dengan suasana yang menyenangkan. Suasana yang menyenangkan diharapkan juga tercipta melalui penggunaan media pembelajaran peta konsep dari barang bekas dan media kartu disusun yang menarik. Dengan adanya inovasi pembelajaran yang menyenangkan ini diharapkan hasil belajar peserta didik meningkat.

Dengan memperhatikan uraian di atas, maka perlu dilakukan penelitian tindakan kelas dengan judul "Penggunaan Powtakon Kardus sebagai Upaya Meningkatkan Hasil Belajar Peserta Didik SDN 2 Kembang Jepara". 
Permasalahan dalam penelitian tindakan kelas ini adalah apakah dengan menggunakan media pembelajaran Powtakon Kardus dapat meningkatkan hasil belajar peserta didik SD Negeri 2 Kembang Jepara?, sedangkan tujuan dari penelitian ini adalah menggunakan media pembelajaran Powtakon Kardus untuk meningkatkan hasil belajar peserta didik SD Negeri 2 Kembang Jepara.

\section{B. Metode}

Penelitian tindakan kelas ini dilaksanakan pada peserta didik kelas V SD Negeri 2 Kembang Kabupaten Jepara Tahun Pelajaran 2019/2020 yang berjumlah 15 peserta didik, sekolah tersebut dipakai sebagai lokasi penelitian karena merupakan sekolah tempat peneliti mengajar sekarang ini.

Penelitian ini peneliti menggunakan model yang dilakukan oleh Kemmis dan Mc Taggart yang merupakan pengembangan dari model Kurt Lewin. Daryanto (2011: 275) mengemukakan bahwa penelitian tindakan kelas terdiri dari empat komponen pokok yang juga menunjukkan langkah, yaitu (1) Perencanaan atau planning, menggambarkan secara rinci hal-hal yang perlu dilakukan sebelum pelaksanaan tindakan; (2) Tindakan atau acting, berisi uraian tahapantahapan tindakan yang akan dilakukan oleh guru dalam pembelajaran dengan menggunakan powtakon kardus (media powtoon, peta konsep dan kartu disusun) untuk meningkatkan hasil belajar peserta didik; (3) Pengamatan atau observing, dilakukan dengan mengamati kinerja guru dan hasil belajar peserta didik setelah mengikuti pembelajaran dengan menggunakan media powtakon kardus. Observasi diarahkan pada poinpoin dalam pedoman yang telah disiapkan peneliti; dan (4) Refleksi atau reflecting, dilakukan dengan cara menganalisis hasil tindakan. Berdasarkan hasil analisis akan diperoleh kesimpulan bagian fase mana yang perlu diperbaiki atau disempurnakan dan fase mana yang telah memenuhi target. Hasil belajar peserta didik dinyatakan mengalami 
peningkatan apabila capaian pada indikator keberhasilan yang telah ditetapkan sesuai target atau bahkan melebihnya.

Data yang digunakan sebagai bahan dasar analisis dalam penelitian ini dibagi menjadi dua, yaitu data primer dan data skunder. Data primer dalam penelitian ini merupakan hasil pengamatan terhadap kegiatan yang dilakukan dalam kegiatan penerapan Powtakon kardus (media powtoon, peta konsep dan Kartu disusun) yang efektif diberikan pada peserta didik kelas V SD Negeri 2 Kembang Kabupaten Jepara dalam rangka upaya peningkatan hasil belajar peserta didik. Data sekunder dalam penelitian ini berupa data yang diperoleh dari dokumen sekolah yang meliputi kegiatan pembelajaran yang dilakukan oleh guru. Data atau informasi yang paling penting untuk dikumpulkan dan dikaji dalam penelitian ini sebagian besar data kualitatif. Informasi tersebut digali dari berbagai sumber data yang digunakan dalam penelitian ini meliputi informasi dari peserta didik, dokumen yang berupa arsiparsip kegiatan pembelajaran maupun hasil ulangan harian peserta didik.

Teknik pengumpulan data merupakan langkah yang paling strategis dalam penelitian karena tujuan utama dari penelitian adalah mendapatkan data. (Sugiyono, 2007: 308). Agar dapat terkumpul data yang berkualitas, peneliti menggunakan berbagai teknik supaya perolehan data dari teknik yang satu dapat dilengkapi dengan perolehan data dengan teknik lain. Adapun teknik pengumpulan data yang digunakan dalam penelitian ini yaitu (1) Observasi, menurut Supardi (2008: 127) observasi adalah kegiatan pengamatan (pengambilan data) untuk memotret seberapa jauh efek tindakan telah mencapai sasaran, penelitian ini menggunakan observasi terstruktur. Observasi menggunakan instrumen yang terstruktur dan siap pakai sehingga pengamat hanya tinggal membubuhkan tanda centang $(\sqrt{ })$ pada tempat yang disediakan dalam mengukur tingkat keterampilan membaca peserta didik. Alasan digunakan observasi terstruktur adalah untuk 
mempermudah observer melakukan pengamatan dan observasi terstruktur sesuai dengan masalah yang diteliti; (2) Dokumentasi adalah cara pengumpulan data melalui peninggalan tertulis seperti arsip-arsip dan termasuk juga buku-buku pentang pendapat, teori, dalil, atau hukum-hukum dan lain-lain yang berhubungan dengan masalah penelitian (Margono, 2009: 161). Dalam penelitian ini, metode dokumentasi digunakan untuk memperoleh data tentang kemampuan awal peserta didik yang berhubungan dengan hasil belajar peserta didik SD Negeri 2 Kembang Kabupaten Jepara tahun pelajaran 2019/2020. (3) Wawancara, atas dasar pengamatan di sekolah selama kegiatan pembelajaran berlangsung maka dilakukan wawancara untuk memperoleh informasi tentang berbagai hal yang berkaitan dengan keterampilan membaca peserta didik.

Hasil belajar dianalisis dengan analisis deskriptif komparatif yaitu membandingkan nilai tes antarsiklus maupun dengan indikator kinerja. Observasi atau pengamatan dianalisis dengan analisis deskriptif berdasarkan hasil observasi dan refleksi. Dalam penentuan skor atau nilai dilakukan dengan aturan hasil belajar peserta didik dalam pembelajaran merupakan jumlah skor yang diperoleh setiap soal di kali 100, hasilnya dibagi dengan skor maksimal

\section{Hasil dan Pembahasan}

Powtoon merupakan sebuah aplikasi layanan online yang digunakan untuk membuat video presentasi atau paparan berupa animasi yang sangat menarik. Banyak fitur animasi yang terdapat pada aplikasi powtoon, di antaranya animasi kartun, animasi tangan, dan efek transisi yang lebih hidup disertai pengaturan timeline yang sangat mudah. Layanan aplikasi animasi ini sangat cocok digunakan untuk membuat media pembelajaran berupa video animasi. Pembelajaran yang dilakukan dengan menggunakan media pembelajaran video animasi powtoon diharapkan dapat membuat peserta didik suka dan senang dengan materi pembelajaran yang berimbas dapat meningkatkan hasil belajar peserta didik. 
Peta konsep merupakan suatu alat skematis untuk mempresentasikan suatu konsep yang digambarkan dalam suatu kerangka preposisi. Peta ini mengungkapkan hubungan-hubungan yang berarti antar konsep-konsep. Peta konsep disusun secara hierarkis, yaitu konsep yang di atas dimulai dengan konsep yang umum atau konsep dasar dan sering disebut konsep kunci. Hubungan antarkonsep dihubungkan dengan garis penghubung, dan pada tiap garis penghubung dibubuhkan keterangan yang menunjukkan hubungan antarkonsep. Dengan demikian akan diperoleh hierarki materi yang mudah dipahami serta mudah diingat.

Langkah-langkah dalam membuat peta konsep adalah sebagai berikut. (1) Memilih dan menetapkan topik yang akan dibahas; (2) Mengidentifikasi dan mendaftar konsep-konsep yang berhubungan dengan materi yang dibahas; (3) Menyiapkan kertas karton, penggaris, spidol, gunting atau cuter; (4) Membuat judul peta konsep, kemudian memotong judul tersebut dan menempelkan pada karton bagian atas; (5) Memuat kalimat perintah, kemudian memotong kalimat perintah tersebut dan menempelkan pada karton di bawah judul peta konsep; (6) Membuat kata-kata sebagai jawaban pada peta konsep, kemudian memotong kata-kata sebagai jawaban pada peta konsep tersebut dan menempelkan pada karton di bawah kalimat perintah; (7) Menggambar peta konsep di bawah kata-kata sebagai jawaban pada peta konsep; (8) Menghubungkan konsep-konsep yang berhubungan dengan garis penghubung; (9) Membuat potongan-potongan kata sebagai jawaban yang nantinya akan ditempel pada peta konsep; (10) Membuat potonganpotongan kata penghubung untuk menghubungkan konsep-konsep yang ada pada peta konsep

Dalam upaya melatih peserta didik untuk membuat peta konsep, yang perlu dilakukan oleh guru adalah sebagai berikut. (1) Memberikan pengertian kepada peserta didik bahwa dengan menggunakan peta konsep, kita akan lebih mudah memahami materi yang telah dipelajari dalam proses pembelajaran karena dengan melihat hubungan antar 
konsep dan peserta didik sadar bahwa mereka telah belajar secara bermakna; (2) Memberikan dorongan kepada peserta didik bahwa cara belajar bermakna akan membantu menyerap suatu pengertian atau konsep-konsep dari kegiatan membaca atau mendengarkan uraianuraian; (3) Memberikan pengertian kepada peserta didik melalui visualisasi konsep-konsep IPS dalam tema peristiwa dalam kehidupan serta hubungannya secara hierarkis

Langkah-langkah dalam pemakaian peta konsep adalah sebagai berikut. (1) Membagi peserta didik menjadi beberapa kelompok; (2) Menempelkan media peta konsep pada papan tulis; (3) Menyiapkan potongan-potongan jawaban pada sebuah kotak; (4) Meminta peserta didik untuk mengerjakan peta konsep dalam kelompok; (5) Meminta pada perwakilan masing-masing kelompok untuk mencari potongan potongan jawaban pada kotak sesuai dengan tugasnya; (6) Meminta pada perwakilan masing-masing kelompok untuk menempelkan potonganpotongan jawaban yang dianggap benar pada media peta konsep.

Media permainan kardus (kartu disusun) adalah potongan potongan bahan bacaan yang berupa kartu-kartu yang jika disusun akan membentuk bahan bacaan, tetapi bahan bacaan tersebut masih terdapat kalimat rumpang. Oleh karena itu, peserta didik diminta untuk melengkapi kalimat rumpang tersebut menjadi bahan bacaan yang utuh. Kartu kartu yang berisi bahan bacaan rumpang tersebut dibuat dengan menggunakan barang bekas, misalnya dari kertas bekas kalender atau yang lainnya. Media permainan kardus yang dibuat oleh peneliti diharapkan dapat meningkatkan semangat belajar peserta didik. Karena dalam pembelajarannya dilakukan dengan bermain sehingga peserta didik dapat belajar sambil bermain. Media pembelajaran ini memfasilitasi peserta didik untuk mengembangkan kegembiraan dalam proses belajar mengajar dan mampu menghilangkan sifat egoisme peserta didik. Suasana yang menyenangkan diharapkan juga tercipta melalui penggunaan media pembelajaran kartu disusun dari barang bekas dalam 
bentuk permainan yang menarik. Dengan adanya inovasi pembelajaran yang menyenangkan ini diharapkan keterampilan membaca dan hasil belajar peserta didik meningkat

\section{Hasil}

Penelitian tindakan kelas ini dilaksanakan pada kelas $\mathrm{V}$ dengan jumlah peserta didik 15 peserta didik pada mata pelajaran Ilmu Pengetahuan Sosial (IPS) dalam tema peristiwa dalam kehidupan di SD Negeri 2 Kembang Kabupaten Jepara, SD tersebut dipilih karena tempat peneliti mengajar saat ini. Penelitian tindakan kelas dilaksanakan dalam dua kali siklus yang dimulai dengan perencanaan, aplikasi dalam pembelajaran meliputi pendahuluan, kegiatan inti, dan penutup.

Penelitian tindakan kelas pada siklus pertama dilaksanakan diawali dengan kegiatan pendahuluan, diikuti kegiatan inti dan penutup. Pada kegiatan pendahuluan, guru sebagai peneliti mengucapkan salam kepada peserta didik, kemudian meminta peserta didik untuk berdoa sesuai agama dan kepercayaan masing-masing dan mengecek kehadiran peserta didik. Setelah itu, guru memberikan apersepsi dan motivasi dengan mengajukan pertanyaan, "Sejak tanggal 17 Agustus 1945 bangsa Indonesia telah memproklamasikan kemerdekaannya. Namun, melalui berbagai cara Belanda tetap ingin menjajah Indonesia. Bagaimana sikap Bangsa Indonesia? Usaha-usaha apa saja yang dilakukan bangsa Indonesia untuk mempertahankan kemerdekaannya?"

Pada kegiatan inti, guru sebagai peneliti menyampaikan informasi berupa materi yang sedang dibahas yaitu perjuangan mempertahankan kemerdekaan. Guru kemudian memutarkan video animasi yang dibuat dengan menggunakan animasi powtoon. Setelah itu, guru meminta peserta didik duduk secara berkelompok untuk mendiskusikan hasil pengamatan video animasi powtoon tersebut dan meminta perwakilan peserta didik dalam kelompok untuk mempresentasikan hasil diskusinya. Kegiatan tersebut dapat dilihat dalam gambar di bawah ini. 


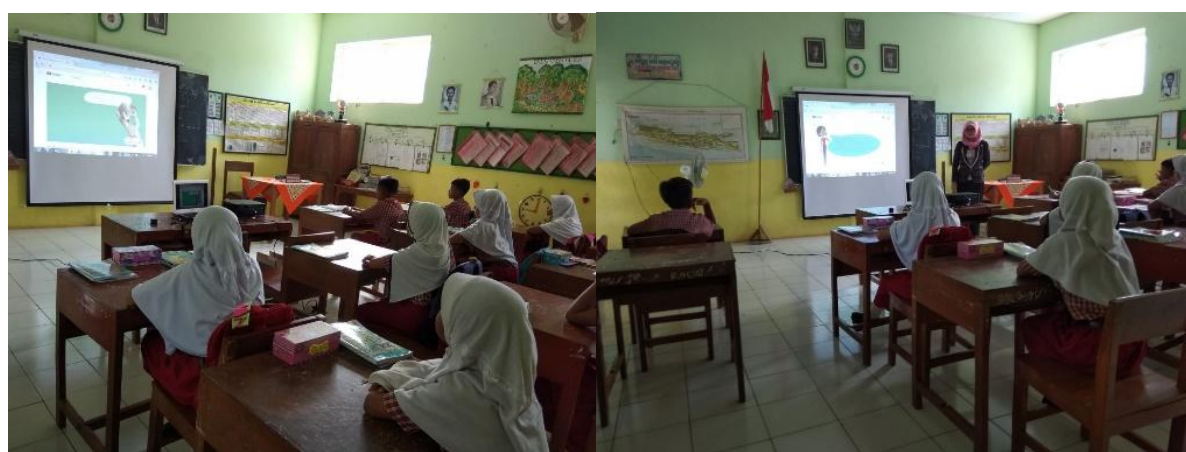

Gambar 1: Suasana Kelas

saat Peserta didik Menyimak Tayangan Video

Setelah semua kelompok sudah mempresentasikan hasil diskusinya, kemudian, dengan bimbingan guru meminta peserta didik untuk mengisi peta konsep yang berhubungan dengan materi perjuangan mempertahankan kemerdekaan. Guru juga memberikan pengertian kepada peserta didik bahwa dengan menggunakan peta konsep, mereka akan lebih mudah memahami materi yang telah dipelajari dalam proses pembelajaran. Dengan melihat hubungan antarkonsep dan peserta didik sadar bahwa mereka telah belajar secara bermakna. Peta konsep tersebut berupa kotak-kotak kosong yang dihubungkan dengan garis hubung dan dilengkapi dengan kata-kata hubung serta ditempel di papan tulis, kotak-kotak kosong tersebut diisi dengan potongan-potongan jawaban yang sudah disediakan. Proses tersebut dapat dilihat pada gambar di bawah ini.

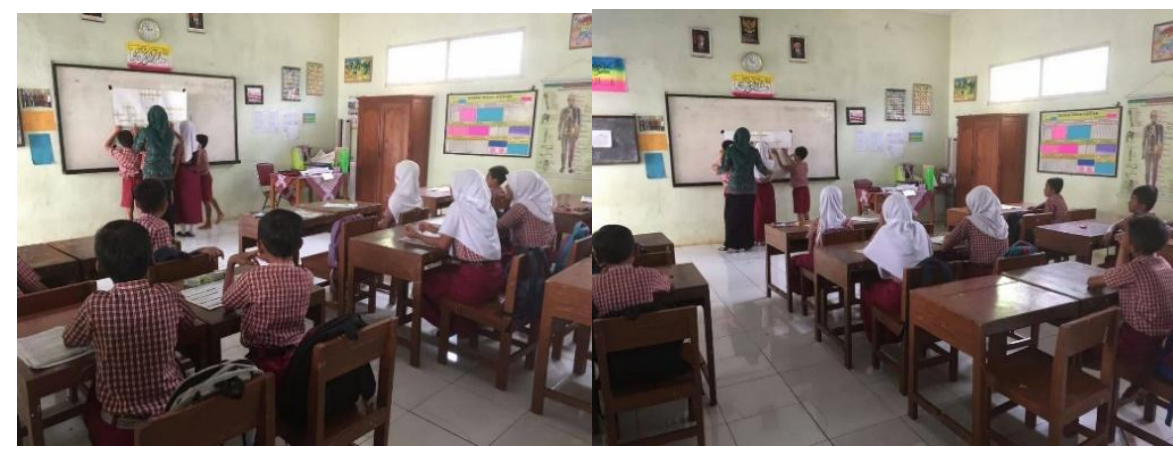

Gambar 2: Peserta didik Menempelkan Potongan Kertas Berisi Jawaban yang Dianggap Benar pada Siklus 1 
Pada kegiatan penutup guru sebagai peneliti bersama-sama peserta didik membuat kesimpulan dari materi yang sudah dibahas. Untuk mengetahui seberapa besar pemahaman peserta didik tentang materi yang sudah dibahas, guru memberikan kuis dengan menggunakan kartu yang disusun. Pada akhir kegiatan untuk mengetahui hasil belajar, peserta didik harus mengerjakan soal ulangan harian.

Penelitian tindakan kelas pada siklus kedua dilaksanakan diawali dengan kegiatan pendahuluan dilanjutkan kegiatan inti dan penutup. Pada kegiatan pendahuluan, guru sebagai peneliti mengucapkan salam kepada peserta didik, kemudian meminta peserta didik untuk berdoa sesuai agama dan kepercayaan masing-masing dan mengecek kehadiran peserta didik. Selanjutnya, guru memberikan apersepsi dan motivasi dengan mengajukan pertanyaan, "Ada banyak tokoh yang terlibat dalam perjuangan mempertahankan kemerdekaan. Ada tokoh-tokoh yang berjuang secara fisik dengan melakukan perang gerilya. Ada juga tokohtokoh yang berjuang lewat jalur perjuangan diplomasi. Siapa di antara kalian yang tahu, nama-nama tokoh tersebut?"

Pada kegiatan inti, guru sebagai peneliti menyampaikan informasi berupa materi yang sedang dibahas yaitu menghargai jasa tokoh-tokoh perjuangan dalam mempertahankan kemerdekaan. Guru kemudian memutarkan video animasi yang dibuat dengan menggunakan animasi powtoon. Setelah selesai menyimak tayangan video, guru meminta peserta didik duduk secara berkelompok untuk mendiskusikan hasil pengamatan video animasi powtoon tersebut dan meminta perwakilan peserta didik dalam kelompok untuk mempresentasikan hasil diskusinya. Kegiatan tersebut dapat dilihat dalam gambar di bawah ini. 


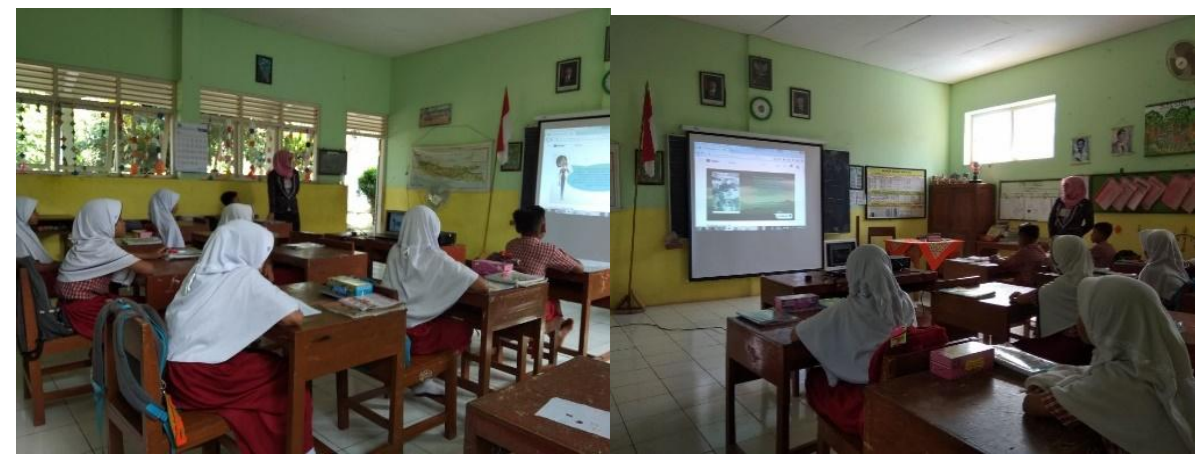

Gambar 3: Peserta didik Menyimak Tayangan Video dalam Pembelajaran Siklus 2

Setelah semua kelompok selesai mempresentasikan hasil diskusinya, kemudian dengan bimbingan guru meminta peserta didik untuk mengisi peta konsep yang berhubungan dengan materi menghargai jasa tokoh-tokoh perjuangan dalam mempertahankan kemerdekaan. Peta konsep tersebut berupa kotak kotak kosong yang yang dihubungkan dengan garis hubung dan dilengkapi dengan kata-kata hubung serta ditempel di papan tulis. Kotak-kotak kosong tersebut diisi dengan potongan-potongan jawaban yang sudah disediakan. Suasana saat peserta didik menempelkan potongan kertas berisi jawaban dapat dilihat dalam gambar di bawah ini.

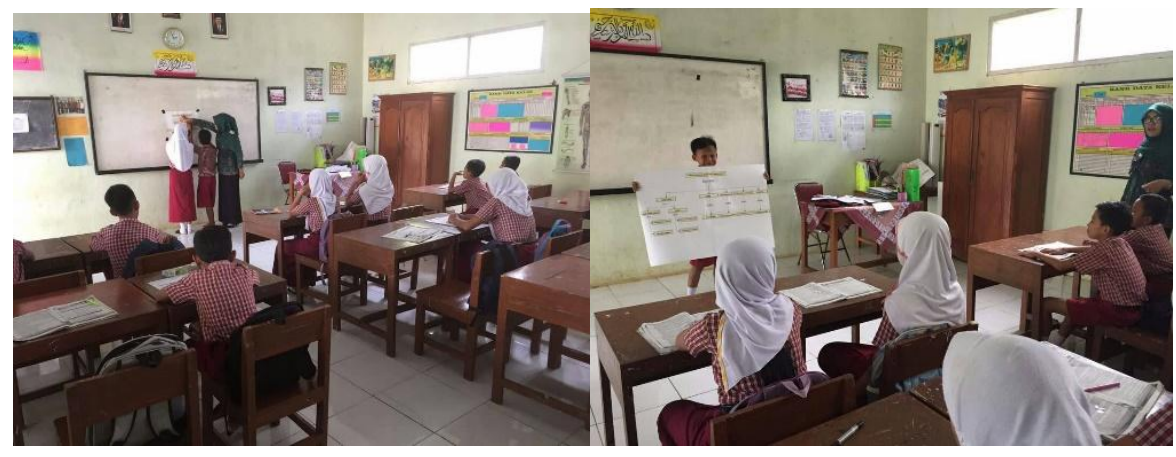

Gambar 4: Peserta didik Menempelkan Potongan Kertas Berisi Jawaban yang Dianggap Benar pada Siklus 2 
Pada kegiatan penutup guru sebagai peneliti bersama-sama peserta didik membuat kesimpulan dari materi yang sudah dibahas, kemudian untuk mengetahui seberapa besar pemahaman peserta didik tentang materi yang sudah dibahas. Guru kemudian memberikan kuis dengan menggunakan kartu yang disusun. Pada akhir kegiatan untuk mengetahui hasil belajar, peserta didik diberikan ulangan harian.

Pelaksanaan penelitian tindakan kelas yang dilakukan pada pembelajaran mengacu pada perencanaan yang telah dibuat. Hasil observasi dari siklus 1 adalah di awal pertemuan banyak peserta didik yang masih merasa grogi dalam mengikuti proses pembelajaran. Pembelajaran yang dilakukan belum sesuai harapan dan masih terdapat beberapa kekurangan. Sebagian besar peserta didik masih pasif dalam berdiskusi kelompok dan kesulitan dalam menyusun peta konsep dan kartu disusun, terutama dalam mengisi kalimat rumpang dari kardus yang sudah tersusun. Hal ini disebabkan mereka belum biasa melakukan kegiatan tersebut. Campur tangan guru sebagai peneliti masih sangat dominan. Guru kurang sekali memberikan penghargaan terhadap peserta didik yang aktif baik secara individu maupun secara kelompok.

Setelah dilakukan refleksi berdasarkan hasil pengamatan dapat disimpulkan bahwa kinerja guru pada siklus 1 perlu ditingkatkan terutama dalam hal pengelolaan kelas. Dengan pengelolaan kelas yang baik, diharapkan perasaan grogi dan merasa diawasi dari peserta didik jadi berkurang.

Hasil kegiatan siklus 2, secara umum peneliti melakukan proses pembelajaran lebih baik dari pada siklus 2. Sebagian besar peserta didik terlibat aktif dalam mengikuti proses pembelajaran terutama pada saat kegiatan pembelajaran dengan menggunakan powtakon kardus dan sebagian besar peserta didik sudah berani dalam mengemukaan pendapatnya saat berdiskusi

Refleksi yang dilakukan antara peneliti dan observer melalui diskusi hasil pengamatan dan temuan pada siklus 2 adalah adanya usaha 
peneliti untuk meningkatkan kinerja dalam pembelajaran bahasa Indonesia dengan menggunakan media pembelajaran berupa powtakon kardus berdampak meningkatnya hasil belajar peserta didik.

\section{Pembahasan}

Meningkatnya hasil belajar peserta didik pada pembelajaran IPS dalam tema peristiwa dalam kehidupan dengan menggunakan media pembelajaran berupa powtakon kardus berbanding lurus dengan pelaksanaan pembelajaran yang dilakukan. Kelemahan yang dijumpai dalam hal pengelolaan kelas terjadi adalah guru kurang memberikan bimbingan pada kelompok belajar dan bekerja. Akibatnya, peserta didik kesulitan dalam menyusun peta konsep dan kartu disusun, sehingga diperlukan tindakan antisipasi berupa pemberian bimbingan pada kelompok belajar dan bekerja sesegera mungkin agar tindakan yang dilakukan semaksimal mungkin sesuai perencanaan yang dibuat.

Hasil belajar peserta didik berdasarkan hasil ulangan harian yang dilaksanakan di akhir pembelajaran siklus 1 dan siklus 2 dapat dilihat pada tabel di bawah ini

Tabel Hasil Belajar Peserta Didik pada Siklus 1 dan Siklus 2

\begin{tabular}{llll}
\hline No & Nilai & Siklus 1 & Siklus 2 \\
\hline 1 & Nilai Minimum & 45 & 66 \\
2 & Nilai Maksimum & 90 & 100 \\
3 & Rata-rata & 66,33 & 81,27 \\
4 & Ketuntasan & $40 \%$ & $86,67 \%$ \\
\hline
\end{tabular}

Dari tabel di atas dapat diketahui bahwa terjadi peningkatan hasil belajar peserta didik. Pada siklus 1, rata-rata nilai 66,33. Peserta didik yang telah tuntas KKM baru mencapai $40 \%$ atau baru 6 orang peserta didik dengan KKM 70. Pada siklus 2 rata-rata nilai 81,27. Peserta didik yang telah tuntas KKM mencapai $86,67 \%$ atau 13 orang peserta didik

Pada saat peserta didik berkelompok, guru menggunakan media powtakon kardus yang berfungsi sebagai salah satu media pembelajaran. 
Dengan menggunakan media pembelajaran berupa powtakon kardus diharapkan kegiatan belajar tidak lagi terpusat pada guru, tetapi terpusat pada peserta didik. Dalam pembelajaran sejatinya peserta didik sendiri yang harus menyelesaikan permasalahan dan mengonstruksi pengetahuannya. Hal ini sesuai dengan pendapat Sanjaya (2009: 162) yang menyatakan bahwa penggunaan media pembelajaran bukan saja dapat mempermudah dan mengefektifkan proses pembelajaran, tetapi juga bisa membuat proses pembelajaran lebih menarik. Peran guru saat belajar kelompok berlangsung adalah sebagai pemimpin, fasilitator, dan motivator. Sebagai seorang pemimpin, guru bertugas untuk mengondisikan dan mengarahkan peserta didik agar proses pembelajaran berlangsung dengan baik. Guru sebagai fasilitator mempunyai tugas memberi bimbingan dan arahan sehingga tidak hanya mendikte peserta didik. Sedangkan guru sebagai motivator bertugas membangkitkan semangat dan minat belajar peserta didik. Hal ini senada dengan pendapat Hamalik dalam Arsyad (2006: 15) bahwa pemakaian media pembelajaran dalam proses belajar mengajar dapat membangkitkan motivasi dan rangsangan kegiatan belajar. Dalam hal ini dapat meningkatkan keaktifan peserta didik dalam belajar.

Aktivitas kegiatan kelompok peserta didik dari siklus 1 dan siklus 2 semakin baik dan secara umum tahapan kegiatan kelompok dapat berjalan dengan baik. Hal ini dapat dilihat dari semakin banyaknya peserta didik yang bekerja sama dalam melakukan kegiatan diskusi maupun menyelesaikan peta konsep kalimat rumpang yang terdapat pada kartu disusun yang sudah disusun peserta didik dan terdapat kalimat rumpang, sehingga menjadi bahan bacaan yang utuh dan lengkap.

Pada siklus 1 sebagian peserta didik belum berani mengemukaan pendapatnya. Tindakan yang dilakukan guru adalah memberikan penghargaan berupa berupa pujian, applause. Dengan diberikannya penghargaan individu maupun kelompok diharapkan dapat memotivasi 
peserta didik untuk lebih aktif dalam pembelajaran dan mendapatkan prestasi yang baik. Berdasarkan hasil wawancara dengan peserta didik, diketahui bahwa mereka termotivasi untuk belajar agar kelompok mereka menang dan mendapat hadiah. Hal ini didukung oleh pendapat Sardiman (2006: 91-94) yang menyatakan pemberian penghargaan dapat meningkatkan motivasi belajar peserta didik. Pemberian penghargaan bisa dilakukan tidak hanya dalam bentuk hadiah, tetapi juga dapat berupa, ungkapan secara verbal, misalnya dengan pujian.

\section{Penutup}

Berdasarkan hasil penelitian yang dilakukan di kelas V SDN 2 Kembang, Kabupaten Jepara tahun pelajaran 2019/2020 dapat disimpulkan bahwa penggunaan media powtakon kardus dapat meningkatkan hasil belajar peserta didik SDN 2 Kembang Jepara

Berdasarkan kesimpulan di atas, saran yang bisa peneliti sampaikan antara lainpenelitian tindakan kelas ini dapat ditindaklanjuti oleh peneliti atau guru-guru kelas untuk mata pelajaran yang lain. Selain itu, guru kelas sangat disarankan dapat membuat media pembelajaran powtakon kardus ini pada tema yang lain. Selain itu, guru kelas harus lebih kreatif dan inovatif dalam pembelajaran agar hasil yang dicapai lebih meningkat.

\section{Ucapan Terima Kasih}

Ucapan terima kasih kami sampaikan kepada Bapak Kepala Sekolah yang telah memberikan izin penelitian ini, rekan rekan guru yang yang telah membantu terlaksananya penelitian ini dan pihak-pihak yang berperan sangat penting dalam pelaksanaan penelitian tindakan kelas ini sehingga terselesaikannya penelitian ini.

\section{Daftar Referensi}

Arsyad, Azhar. (2006). Media Pembelajaran. Jakarta : Raja Grafindo Persada 
Daryanto. (2011). Penelitian Tindakan Kelas dan Penelitian Tindakan Sekolah. Yogyakarta: Gava Media.

Indriana, Dina. (2011). Ragam Alat Bantu Media Pengajaran. Jakarta: Diva Press

Margono. (2009). Metode Penelitian Pendidikan. Jakarta: Rineka Cipta.

Miarso, Yusufhadi. (2011). Menyemai Benih Teknologi Pendidikan. Jakarta: Kencana Prenada Media Group.

Prastowo, Andi. (2012). Panduan Kreatif Membuat Bahan Ajar Inovatif. Yogyakarta: Diva Press.

Sanjaya, W. (2009). Strategi Pembelajaran Berorientasi Standar Proses Pendidikan. Jakarta: Kencana Prenada Media Group

Sardiman. (2006). Inovasi dan Motivasi Belajar Mengajar. Jakarta: Raja Grafindo Persada.

Siswanto, R., Sugiono, S., \& Prasojo, L. (2018). The Development of Management Model Program of Vocational School Teacher Partnership with Business World and Industry Word (DUDI). Jurnal Ilmiah Peuradeun, 6(3), 365-384. doi:10.26811/peuradeun.v6i3.322

Sugiyono. (2007). Penelitian Kualitatif dan Kuantitatif. Yogyakarta: Pustaka Pelajar.

Supardi. (2008). Penelitian Tindakan Kelas (Classroom Action Research) Beserta Sistematika Proposal dan Pelaporannya. Jakarta: Bumi Aksara 